\title{
ILDIKÓ BARNA AND JÚLIA KOLTAI * Attitude Changes towards Immigrants in the Turbulent Years of the 'Migrant Crisis' and Anti-Immigrant Campaign in Hungary
}

Intersections.EEJSP

$5(1): 48-70$.

DDI: 10.17356/ieejsp.v5il.5미

http://intersections.tk.mta.hu

* [koltai.julia@tk.mta.hu] (Centre for Social Sciences, Hungarian Academy of Sciences; Faculty of Social Sciences, Eötvös Loránd University); [barnaildiko@tatk.elte.hu] (Faculty of Social Sciences, Eötvös Loránd University)

\begin{abstract}
The paper discusses explanations for attitudes towards immigrants before and after the start of the 'migrant crisis'. Though the crisis caused changes in peoples' attitudes all over Europe, the Hungarian case is special due to the Hungarian government's intensive antiimmigration campaign. To explain the circumstances people encountered during the crisis and the campaign, we first prove that moral panic abounded in society. Then, we show the background effects which affected the emergence of attitudes towards immigration in a political context. In the second part of the paper, we introduce a path model to explain the presumed effect of migration. We analyze this model with regard to the different political party preference groups, assuming that the government's anti-immigration campaign affected people's opinions and that people with different party preferences had different attitudes towards immigration: namely, those who were sympathetic to the incumbent party had more negative attitudes towards immigration. This effect has two interpretations. The first is that those who sympathized with the incumbent party were more sensitive to its messages. The other is that those who resonated more with the campaign changed their party preference to favour Fidesz, but those who resonated less with the campaign but used to be sympathizers of Fidesz do not support them anymore. The models show that before the migrant crisis there were only slight differences between political preference groups regarding how anti-migrant attitudes arose. However, after the start of the crisis (and the campaign), diverse processes could be identified in the different political groups, especially in the case of Fidesz sympathizers.
\end{abstract}

Keywords: migration crisis, anti-immigration campaign, moral panic, Hungary, attitudes toward migrants. 


\section{Introduction}

In the second half of 2014, after winning the parliamentary election, the popularity of the governing party of Hungary, Fidesz, had fallen sharply as various scandals eroded its popularity. Fidesz found a quick solution by launching an anti-immigration campaign using the tools of propaganda (Barna, 2019). In January 2015, long before the visible outbreak of the migration crisis but right after the solidarity march in Paris, Hungarian prime minister Viktor Orbán told a reporter from the Hungarian nationwide public television channel M1 that 'We [Hungarians] do not want to see minorities of significant size with different cultural characteristics and backgrounds among us. We want to keep Hungary as Hungary." This signaled the start of the government's enduring anti-immigration campaign.

Moral panic has already been used as a framework for the analysis of the antiimmigration campaign and the related political and social turbulence about the migration crisis in Hungary (Bernáth and Messing, 2015; Barlai and Sik, 2017; Walker and Győri, 2018). However, adding to previous analyses, we concentrate on the five crucial elements of moral panic defined by Goode and Ben-Yehuda (2002).

Our paper shows that in Hungary, all five elements - namely, concern, hostility, substantial and widespread consensus, disproportion, and volatility - are present. In addition, we show how an analysis of data from the European Social Survey (ESS) also supports this interpretation. We have two main hypotheses. The first is that the rejection of different immigrant groups increased and respondents' assumptions about the effect of immigration worsened from 2012 to 2017. Our second hypothesis is that attitudes toward migrants and the model that explains these attitudes changed differently for Fidesz and non-Fidesz sympathizers from 2012 to 2017 . We assumed that we could identify these differences not only at the level of descriptive statistics but also in the way the rejection of immigration came into existence; namely, in differences in the models that explain the presumed effects of immigration.

\section{Social context: Moral panic and its Hungarian case}

In 1972, Stanley Cohen published a seminal work about moral panics (Cohen, 2002) which he defined as follows:

'A condition, episode, person or group of persons emerges to become defined as a threat to societal values and interests; its nature is presented in a stylized and stereotypical fashion by the mass media; the moral barricades are manned [...]; socially accredited experts pronounce their diagnoses and solutions; ways of coping are evolved or (more often) resorted to; the condition then disappears, submerges or deteriorates and becomes more visible.' (Cohen, 2002: 1)

Later, Goode and Ben-Yehuda identified five crucial elements of moral panic. The first is concern over the behavior of a certain group. The authors also underline that

' M1 Evening News: https://nava.hu/id/2066608\#. The quoted section starts from 5:51. Accessed: 22-092018. 
this concern should be measurable in some concrete way (Goode and Ben-Yehuda 2002: 37). In the Hungarian context, the results of the standard Eurobarometer survey clearly showed that immigration had become one of the major concerns of Hungarians: while in November 2014 only four per cent of the Hungarian population listed immigration as one of the most important issues Hungary was facing, in May 2015 the number was 13 per cent, while in November 2015 it peaked at 34 per cent, and was thus the number one concern of Hungarians. ${ }^{2}$

The second element listed by Goode and Ben-Yehuda (2002: 38) is hostility toward a group when the members of the given group are perceived as threats to and enemies of society. In Hungary, xenophobia, or in other words hostility against immigrants was already widespread before the anti-immigration campaign but increased after it started. TÁRKI, a Hungarian research institute primarily engaged in applied social science, has been using the same question to measure xenophobia since 1992. The organization found that in $2012^{3}$ the proportion of xenophobes in the sample was 40 per cent and this had increased to 53 per cent by the beginning of 2016 (Sik, 2016). This same increase can also be observed using ESS data, as discussed in the next chapter. It is also important to note that xenophobia was already strong before the campaign started, which made the anti-immigrant propaganda even more successful (Barna, 2019). Some authors have focused on another aspect of hostility: the utilization of enemy images (Gerő et al., 2017) and scapegoats (Kovarek et al., 2017) used by mainstream and far-right Hungarian politics. Csepeli and Örkény (2017) argued that the overall hostility present in society is embedded in a moral crisis.

The third element which characterizes conditions as moral panic is a substantial or widespread consensus that the threat posed by the group is real and serious, and that this threat is the responsibility of the group members (Goode and Ben-Yehuda, 2002: 38-40). In Hungary the former consensus is clear according to a survey by the Pew Research Center carried out in 2016 which showed that 70 per cent of Hungarians found ISIS to be a major threat to the country, and 76 per cent of Hungarians thought that the presence of refugees would increase the likelihood of terrorism in Hungary (Wike, 2016). The government thus created a link between migration and terrorism from the very beginning of their campaign. This became crystal clear when in April 2015 the government launched a 'National Consultation" on Immigration and Terrorism.' The rhetoric of the government also linked migration to crime and unemployment, and instead of calling immigrants asylumseekers or refugees used expressions such as 'economic migrants,' 'illegal migrants' or 'subsistence migrants' (Barna and Hunyadi, 2016: 16-21).

The fourth element, according to Goode and Ben-Yehuda (2002: 40-41), is that there is disproportion between the perception and the actual threat, danger and

\footnotetext{
${ }^{2}$ Source: http://ec.europa.eu/commfrontoffice/publicopinion/index.cfm

${ }^{3}$ The year when the first ESS survey we use was carried out.

'The 'national consultation' is an institutionalized political survey aimed at 'discuss[ing] every important issue before decisions are taken' (Letter of the Prime Minister included in the national consultation on immigration and terrorism). Since 2010, there have been eight national consultations in which a 'questionnaire' accompanied by the Prime Minister's letter was sent out to every eligible voter. The questionnaires are constructed in a way that disregards the rules of quantitative social research methodology. The data processing of the questionnaires lacks any transparency and the public has to rely completely on results published by the government. All national consultations are financed through taxes.
} 
damage caused by the given group. In replying to some critics Goode and BenYehuda admit that it may be difficult or even impossible to objectively measure this disproportion. However, the authors claim that there are cases when we can be reasonably sure of such disproportions. We argue that the situation in Hungary is one such case.

Table 1. Number of asylum-seekers arrived to, foreign citizens residing in, and foreign citizens immigrating to Hungary (2015 - 2017)

\begin{tabular}{|c|r|r|r|}
\hline & $\begin{array}{c}\text { Number of asylum- } \\
\text { seekers arrived to } \\
\text { Hungary }\end{array}$ & $\begin{array}{c}\text { Number of foreign } \\
\text { citizens residing in } \\
\text { Hungary }\end{array}$ & $\begin{array}{c}\text { Number of foreign } \\
\text { citizens } \\
\text { immigrating to } \\
\text { Hungary }\end{array}$ \\
\hline 2015 & 177,135 & 145,968 & 25,787 \\
\hline 2016 & 29,432 & 156,606 & 23,803 \\
\hline 2017 & 3,397 & 151,132 & 36,453 \\
\hline
\end{tabular}

Source: Hungarian Central Statistical Office

http://www.ksh.hu/docs/eng/xstadat/xstadat_annual/i_wnvn002b.html http://www.ksh.hu/docs/eng/xstadat/xstadat_annual/i_wnvn001b.html http://www.ksh.hu/docs/eng/xstadat/xstadat_annual/i_wnvn005b.html (last download: 29 January, 2019)

As Table 1 shows, the number of foreign citizens residing in Hungary is less than two per cent of the total Hungarian population, even if we include the number of foreign citizens who immigrated into Hungary in the given year. This proportion is very low compared to the other EU Member States. In 2015, ${ }^{5}$ Hungary was ranked twenty-first among the twenty-eight Member States according to the number of non-nationals in the resident population. Both in $2016^{6}$ and $2017^{7}$ it was twenty-second. It is also important to mention that the number of asylum-seekers declined dramatically from 2015 to $2016 / 2017$, which can be explained by the physical closure of Hungary in the form of a fence on Hungary's southern border in September 2015. The intention of the government to close the country to migrants was also backed by administrative measures. However, a lack of migrants did not decrease the level of fear: on the contrary, the latter increased. The level of xenophobia measured by TÁRKI kept increasing after 2015. Moreover, people felt the need to always remain cautious. There were many examples of residents raising objections not only verbally but often in a fierce and aggressive way against migrants who had already been granted international protection by the Hungarian state. It is important to note that these incidents were always supported by government politicians; in one of the most severe cases, PM Viktor Orbán found such outrage to be an appropriate reaction ${ }^{8}$ (Pivarnyik,

${ }^{5}$ Source: https://ec.europa.eu/eurostat/statistics-explained/images/7/74/Share_of_nonnationals_in_the_resident_population\%2C_1_January_2015_\%28\%25\%29_YB16.png

${ }^{6}$ Source: https://ec.europa.eu/eurostat/statistics-explained/index.php?title=File:Share_of_nonnationals_in_the_resident_population,_1_January_2016_(\%25).png

${ }^{7}$ Source: https://ec.europa.eu/eurostat/statistics-explained/index.php?title=File:Share_of_nonnationals_in_the_resident_population,_1_January_2017_(\%25).png\#filehistory

${ }^{8}$ Residents of Ốcsény, a village in Southern Hungary, used force in protest against refugees, mostly women and children, who would have spent a few days vacationing there. A few days later, PM Viktor Orbán was asked whether he placed any responsibility on the government for inciting such hatred that led 
2017; Spike, 2017a; Spike, 2017b). In other cases, distrust and suspicion went so far that women were attacked on the street for wearing a headscarf following a visit to the hairdresser (Boros, 2018), and panic broke out in a small town when residents thought that visitors to a cemetery on All Saints' Day were migrants (Rényi, 2017). Even these examples - and there are many others - show the disproportion between the real situation and the reactions to it. Barna and Koltai found that a sense of realistic and symbolic threats are important explanatory factors of attitude towards migrants (Barna and Koltai, 2018).

In creating and maintaining this disproportionality, mass media, especially progovernment media, played a pivotal role. Cohen has identified mass media as one of the most important actors in situations of moral panic, seeing the role of mass media as having three components: (1) exaggeration and distortion, (2) prediction, and, (3) symbolization (Cohen, 2002: 26-41). In Hungary, the media's exaggerated attention to the 'migration crises' touched 'a responsive chord in the general public' (Goode and Ben-Yehuda, 2002: 25) which made the outbreak and the maintenance of a moral panic possible. Pro-government media, whose share of the media market has increased to an enormous proportion, have constantly spread the government's antiimmigration campaign messages. These media outlets not only exaggerated the seriousness of events but frequently distorted information. The latter practice included using untrue elements in the news, but also another type of distortion (Bernáth and Messing, 2016; Barlai and Sik, 2017; Goździak and Márton, 2018) mentioned by Cohen (2002: 36): when reality did not meet expectations, those elements that strengthened expectations were emphasized and repeated, while contradicting ones were played down. Prediction was also an integral part of the news about the migration crisis, meaning that the former 'present[ed] in virtually every report that what had happened was inevitably going to happen again' (Cohen, 2002: 35). The media's role of symbolization, according to Cohen, rests on the symbolic power of words and images. This process can make even neutral words symbolize complex ideas and emotions, as occurred in Hungary. Just to mention one example, the word 'migrant' (migráns),' which used to have neutral connotations, has for many now became a symbol for the enemy. Bernáth and Messing (2015; 2016) extensively examined coverage of the refugee crisis by the Hungarian media and its role in spreading xenophobia. Their analysis demonstrates the roles of the media mentioned above. Among other factors, the authors stress this role by arguing that 'the government's dehumanizing terminology about illegal migrants, welfare migrants and illegal trespassers [...] was reproduced in media reporting' (Bernáth and Messing, 2016: 59) and emphasize the significant role the pro-government media played in this. Moreover, the authors conclude that the subversive terminology used by these media outlets also penetrated other media.

Returning to the list by Goode and Ben-Yehuda (2002: 41-43), the fifth element of a moral panic is its volatility by nature. We already know that panic

to this event. His response was the following: 'I cannot find anything wrong with this. People do not want to accept migrants. They do not want to accept them into their country and they do not want to accept them into their village.'

${ }^{9}$ There are other words that could be used. For example, the etymologically Hungarian word for refugee (menekült) or for immigrant (bevándorló) and asylum-seeker (menedékkérö). 
erupted very suddenly. However, as it started only three years ago, it is too early to predict how, and especially when, it will end.

\section{Conceptual context}

After describing the social context of the government's anti-immigration campaign and the moral panic it caused, in this part of our paper we deal with the conceptual background of our analysis. The starting point lies in the assumption that supporters of different political parties reacted differently to the migration crisis and the campaign. Political cleavages have been an important characteristic of Hungarian society (Bértoa, 2014; Enyedi, 2004; Kmetty, 2014; Körösényi, 2013; Soós, 2012). Previous research has proved that left-right self-identification is the most appropriate measure for grasping these political-ideological cleavages in Hungary (Angelusz and Tardos, 2005; Kmetty, 2014; Tóka, 2005). In her analysis of 21 European countries, Rustenbach (2010) found that left-right political leaning had a significant effect on attitudes toward migrants, those on the right being more negative. However, in 2016 Pew Research in its Global Attitudes Survey showed that in Hungary people from the political left and right were equally concerned about the threat of migration. We can conclude that although political cleavages are deep in Hungarian society, in the case of attitudes towards immigrants these cleavages are not distributed along the left-right political scale but are more identifiable along party preferences. Several researchers (Boda and Simonovits, 2016; Simonovits and Szeitl, 2016; Simonovits et al., 2016) have found that Fidesz and Jobbik supporters were the most xenophobic, and those of the Hungarian Socialist Party the least. This is why we can hypothesize that attitudes towards immigration differ among the supporters of different political parties.

Beside the possibility that supporters of different parties differ in terms of the degree of their anti-immigrant attitudes, it is also plausible that how these attitudes are constructed is different. Considering the background effects which form attitudes towards immigrants in the different political preference groups, we can separate macro- and also micro-level effects. Trust and satisfaction are important factors in both types.

Paas and Halapuu (2012) found that people who score higher on political trust are more tolerant. Sides and Citrin (2007) as well as Herreros and Criado (2009) found that economic satisfaction decreases opposition to migration. Beside these factors, macro-level trust and satisfaction can be interpreted as having perceived legitimacy potential. This interpretation is similar to that of Ceobanu and Escandell's assumption that '[i]nstitutional legitimacy reflects a country's socio-political and economic system and represents a type of national solidarity based on inclusion and inclusiveness' (Ceobanu and Escandell, 2008: 1151). The authors not only found that a higher level of institutional legitimacy is associated with lower level of anti-immigrant sentiments, but also that this effect is especially strong in Eastern Europe. Since Fidesz's political campaign played an inevitable role in spreading anti-immigrant thought, we assume that the level of legitimacy people assigned to the system affected the degree to which they believed the government's campaign, and could have led to different patterns in their attitudes toward immigrants.

As mentioned above, trust and satisfaction are important factors in the emergence of attitudes towards immigrants, not only at a macro- but at a micro-level 
too. McLaren argued that a sense of personal threat, which is closely connected with anti-immigrant attitudes (Barna and Koltai, 2018), 'may result from other sources of distress and unhappiness' (McLaren, 2003: 915), hypothesizing that respondents who are unhappy and dissatisfied with their lives are "more likely to blame an out-group such as immigrants and to believe that members of this out-group are contributing to negative personal conditions.' In a study, the author found that these hypothesized processes were significant. (McLaren, 2003, 919.)

There is wide consensus about the effect of generalized trust on prejudices in general, and anti-migration attitudes in particular. As Uslaner argued, generalized trusters (i.e. those who trust other people) 'are more tolerant of people who are different from themselves, [and] they are supportive of racial minorities and immigrants [...]' (Uslaner, 2008: 291). Ekici and Yucel (2015), after analyzing thirtyseven European countries included in the European Values Study, found that interpersonal trust decreases religious and racial prejudice. Various researchers (Herreros and Criado, 2009; Rustenbach, 2010; van der Linden et al., 2017) have included generalized trust in their explanation of anti-migrant attitudes in analyses of ESS data. In all the combinations of independent variables, interpersonal trust has been shown to have a strong and significant effect on anti-migrant attitudes: those who trust other people more reject immigrants less.

Sides and Citrin (2007) included both social trust and life satisfaction in their analysis, and both variables proved to be highly significant. Their results show that a higher level of social trust and life satisfaction produce weaker anti-immigrant attitudes. Although Boelhouwer (2016) and Meuleman et al. (2016) compared countries based on attitudes toward migrants, level of life satisfaction, and social trust in the overall population, they found that countries where people are more satisfied with their lives and trust other people more tend to have more positive attitudes toward immigrants.

\section{Data and methods}

For examining the differences between attitudes before and after the Hungarian government's anti-immigration campaign we chose the Hungarian dataset of the European Social Survey (ESS). We used data from the sixth and the eighth round. The Hungarian process of data collection for the sixth round of ESS took place mostly during the last two months of 2012 (less than six per cent of cases were administered at the beginning of 2013), while round eight data was collected in the middle of 2017. The reason we omitted the seventh round was that the related process of data collection in Hungary started four months after the prime minister's first speech about the exclusion of immigrants, and at just the same time as the 'National Consultation on Immigration and Terrorism' was launched. Thus, these campaigns could have already had some effects on the results (however, since they had only just started, not enough time had passed for them to have a clear effect on people's opinions). This is the reason we chose one dataset for which data had been collected before the anti-immigration campaign, and another the data for which was collected a considerable time after the campaign had entered into force. 
We analyzed changes in attitudes towards immigration from two perspectives: allowance of different immigrant groups, and presumed effect of migration. We measured allowance for different immigrant groups through the following questions:

- To what extent do you think Hungary should allow people of the same race or ethnic group as most Hungarian people to come and live here?

- How about people of a different race or ethnic group from most Hungarian people?

- How about people from the poorer countries outside Europe?

Respondents could choose one of four answers: 'allow many,' 'allow some,' 'allow a few,' and 'allow none.' For the analysis of these questions we used descriptive statistics (namely, the proportion of respondents who would allow 'only a few' or 'none' of these immigrants).

We examined the presumed effect of migration using the following questions:

- Would you say it is generally bad or good for Hungary's economy that people come to live here from other countries?

- And, would you say that Hungary's cultural life is generally undermined or enriched by people coming to live here from other countries?

- Is Hungary made a worse or a better place to live by people coming to live here from other countries?

Respondents were asked to indicate their answer using a scale of $0-10$. We created an index that measured the presumed effect of migration, defined as the mean of the three variables, as our goal was to compare the changes between the two time points. ${ }^{10}$

For explaining the presumed effect of migration, we used three constructs. For each of these we created an index from the mean of the items on a scale of ()-10.

The first construct concerned trust in other people (generalized trust), which we built using the following items:

- Would you say that most people can be trusted, or that you can't be too careful in dealing with people?

- Do you think that most people would try to take advantage of you if they got the chance, or would they try to be fair?

- Would you say that most of the time people try to be helpful or that they are mostly looking out for themselves?

The second construct was the respondents' positive outlook on life, measured by the following questions:

- Taking all things together, how happy would you say you are?

\footnotetext{
${ }^{10}$ Principal component analysis could also have been an appropriate solution. However, this would not have been useful as its values are standardized and are thus not comparable across different time points. Also, we did not use weights in the process of index creation as the weights of the earlier analyzed principal component were quite similar to each other, as well as very high.
} 
- All things considered, how satisfied are you with your life as a whole nowadays?

The third construct was the legitimacy potential of the respondent. Legitimacy potential was, on the one hand, measured by trust in different institutions with the following questions:

How much do you personally trust each of the following institutions?

- The Hungarian parliament

- Legal system

- Police

- Politicians

- Political parties

On the other hand, the measurement of legitimacy potential also included questions about satisfaction, such as:

- On the whole, how satisfied are you with the present state of the economy in Hungary?

- Thinking about the Hungarian government, how satisfied are you with the way it is doing its job?

- And on the whole, how satisfied are you with the way democracy works in Hungary?

- Please tell us what you think overall about the state of education in Hungary nowadays.

- Please tell us what you think overall about the state of health services in Hungary nowadays.

To measure the complex relationships between these constructs we used path model analysis, where the final dependent variable was the presumed effect of migration, which is explained by the positive outlook of people, their generalized trust, and legitimacy potential. We also assumed that legitimacy potential has some effect on positive outlook and generalized trust, as we hypothesized that a positive outlook affects general trust. We controlled the model for several socio-demographic factors including gender, age, education, type of settlement, and subjective income." The theoretical model can be seen in Figure 1.

\footnotetext{
"These demographic variables do not have strong effects on the variable that measures the presumed effect of migration. This is especially the case when their effects are controlled for other variables in the model, and when their effect sizes are compared to those of the latter. We thus decided not to display the demographic variables in the figure as they were only used to control effects at every step of the model.
} 


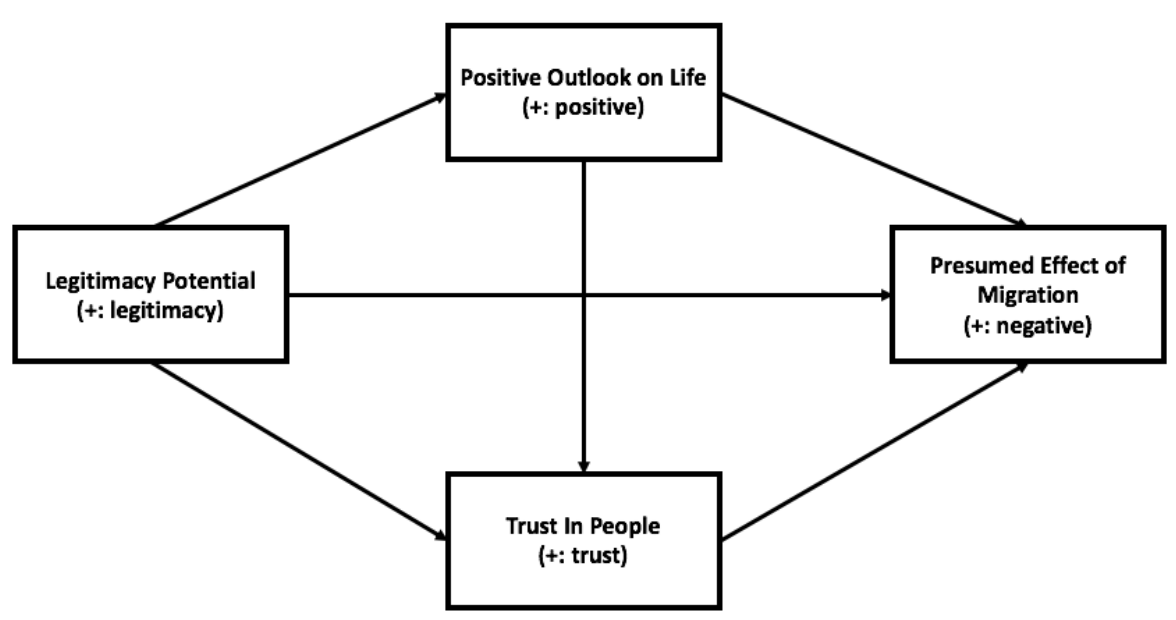

Figure 1. Theoretical path model of the presumed effect of migration

As mentioned in the chapter about the conceptual context, attitudes toward immigrants may have been influenced by the Hungarian government's antiimmigration campaign. As political cleavages in Hungarian society are immensely wide (Kmetty, 2015), we assumed that these attitudes depend (beside other factors) on people's political preferences. We originally hypothesized that the campaign had a stronger effect on those who sympathized with the governing parties (Fidesz and KDNP) than on those who did not. Nevertheless, another theoretical explanation exists for these processes. It is possible that those who were Fidesz voters in 2012 but did not resonate with the anti-immigration campaign no longer sympathized with Fidesz by 2017, while those who were not Fidesz supporters in 2012 and resonated with the anti-immigration campaign had joined the group of Fidesz sympathizers by 2017. We can also assume that both explanations are simultaneously valid. Though the first explanation seems more plausible, we cannot disqualify the second one as it would only be possible to measure attitude changes with panel data which we do not have access to. Accordingly, we hypothesize that these changes exist and there may be diverse mechanisms behind them.

To test our hypotheses, we included the dimension of political preferences in the analysis and split our results not only according to Round Six and Round Eight of ESS, but also by political preferences. Political preferences were measured by a nominal variable with four categories based on a question about the party the respondent felt closest to. ${ }^{12}$ The categories of the variable were the following: Fidesz

\footnotetext{
${ }^{12}$ The original question was the following: 'Is there a particular political party you feel closer to than all the other parties?' It is important here to mention that we could not use the question 'Which party did
} 
sympathizer, ${ }^{13}$ Jobbik sympathizer, other party sympathizer, and no party the respondent feels close to. It is important to note that the group of 'other' party sympathizers consists mostly supporters of left-leaning parties such as MSZP, DK, etc.

\section{Results}

As we mentioned above, allowing different immigrant groups into Hungary was measured by three questions that asked about different types of immigrant groups: those who were (1) from the same race/ethnic group as the majority population in Hungary; (2) those from a different race/ethnic group to the majority; and (3) those from poorer countries outside Europe. The answers were 'allow many to come and live here,' 'allow some,' 'allow a few,' and 'allow none.' Table 2 shows the proportion of responses 'allow a few' and 'allow none' - those which point more in the direction of opposing migration - for the different rounds of ESS and the different party preference groups.

Table 2. Proportions of those who would only allow 'a few' or 'none' of the different types of immigrants into Hungary (row percentages of the given subsample) (\%)

\begin{tabular}{|c|c|c|c|c|}
\hline & & Allow a few & Allow none & Total \\
\hline \multirow{8}{*}{$\begin{array}{l}\text { Allow many/few } \\
\text { immigrants of } \\
\text { same race/ethnic } \\
\text { group as majority }\end{array}$} & $\begin{array}{l}2012 \text { - Fidesz-KDNP } \\
\text { sympathizer }\end{array}$ & 31.1 & 5.4 & 36.5 \\
\hline & 2012 - Jobbik sympathizer & 25.3 & 20.5 & 45.8 \\
\hline & $\begin{array}{l}2012 \text { - other party } \\
\text { sympathizer }\end{array}$ & 36.1 & 15.4 & 51.5 \\
\hline & 2012 - feels close to no party & 35.0 & 15.6 & 50.6 \\
\hline & $\begin{array}{l}2017 \text {-Fidesz-KDNP } \\
\text { sympathizer }\end{array}$ & 15.1 & 31.6 & 46.7 \\
\hline & 2017 - Jobbik sympathizer & 15.6 & 34.8 & 50.4 \\
\hline & $\begin{array}{l}2017 \text { - other party } \\
\text { sympathizer }\end{array}$ & 27.4 & 11.4 & 38.8 \\
\hline & 2017 - feels close to no party & 24.6 & 23.6 & 48.2 \\
\hline \multirow{4}{*}{$\begin{array}{l}\text { Allow many/few } \\
\text { immigrants of } \\
\text { different } \\
\text { race/ethnic group } \\
\text { from majority }\end{array}$} & $\begin{array}{l}2012 \text { - Fidesz-KDNP } \\
\text { sympathizer }\end{array}$ & 45.7 & 24.5 & 70.2 \\
\hline & 2012 - Jobbik sympathizer & 35.1 & 44.1 & 79.2 \\
\hline & $\begin{array}{l}2012 \text { - other party } \\
\text { sympathizer }\end{array}$ & 42.5 & 25.8 & 68.3 \\
\hline & 2012 - feels close to no party & 42.0 & 25.5 & 67.5 \\
\hline
\end{tabular}

you vote for in the last election?' as in both years at the time of data collection too much time (a minimum of one year) had passed since the elections thus respondents might have changed their party preferences since then.

${ }^{13}$ During the analysis, we applied the label 'Fidesz sympathizers' to this group as KDNP is a micro-party that always collaborates in elections with Fidesz. 


\begin{tabular}{|l|l|c|c|c|}
\hline & Allow a few & Allow none & Total \\
\hline \multirow{4}{*}{} & $\begin{array}{l}\text { 2017 - Fidesz-KDNP } \\
\text { sympathizer }\end{array}$ & 31.7 & 59.4 & 91.1 \\
\cline { 2 - 5 } & 2017 - Jobbik sympathizer & 30.9 & 57.7 & 88.6 \\
\cline { 2 - 5 } & $\begin{array}{l}\text { 2017 - other party } \\
\text { sympathizer }\end{array}$ & 44.2 & 25.5 & 69.7 \\
\cline { 2 - 5 } & 2017 - feels close to no party & 38.1 & 43.4 & 81.5 \\
\hline \multirow{4}{*}{$\begin{array}{l}\text { Allow many/few } \\
\text { immigrants from } \\
\text { poutside Europe }\end{array}$} & $\begin{array}{l}\text { 2012 - Fidesz-KDNP } \\
\text { sympathizer }\end{array}$ & & & \\
\cline { 2 - 5 } & 2012 - Jobbik sympathizer & 36.6 & 53.3 & 89.9 \\
\cline { 2 - 5 } & $\begin{array}{l}\text { 2012 - other party } \\
\text { sympathizer }\end{array}$ & 37.0 & 37.2 & 74.2 \\
\cline { 2 - 5 } & 2012 - feels close to no party & 37.4 & 33.9 & 71.3 \\
\cline { 2 - 5 } & $\begin{array}{l}\text { 2017 - Fidesz-KDNP } \\
\text { sympathizer }\end{array}$ & 21.3 & 74.9 & 96.2 \\
\cline { 2 - 5 } & 2017 - Jobbik sympathizer & 24.1 & 70.9 & 95 \\
\cline { 2 - 5 } & $\begin{array}{l}\text { 2017 - other party } \\
\text { sympathizer }\end{array}$ & 47.9 & 34.7 & 82.6 \\
\cline { 2 - 5 } & 2017 - feels close to no party & 31.4 & 55.9 & 87.3 \\
\hline
\end{tabular}

Source: ESS6 and ESS8 Hungarian dataset. Authors' own calculations.

The first group of these questions were asked about immigrants of same race/ethnic group as the majority, which in our case basically referred to ethnic Hungarians of other countries. In 2012, rejection of the immigration of same race/ethnic groups was lowest among Fidesz and Jobbik sympathizers and the highest among the sympathizers of other parties and those, who did not have a party preference. However, these proportions had changed by 2017. Rejection of allowance of ethnic Hungarian immigrants became stronger from 2012 to 2017 among Fidesz and Jobbik sympathizers; the change was bigger (almost ten percentage points) among the former group, and much smaller in the case of the latter (less than five percentage points). Among Fidesz sympathizers especially, the proportion of respondents who would allow no one into the country increased considerably from 5.4 to 31.6 per cent. At the same time, the rejection of ethnic Hungarian immigrants decreased significantly among other party sympathizers (by almost 13 percentage points) and was somewhat lower (by more than two percentage points) among those having no party preference.

Focusing on the rejection of the immigration of people of different race/ethnic groups (non-Hungarians), we can observe growth in almost every party preference group with the only exception of 'other party' sympathizers, where growth was not significant. In 2012, the level of rejection was already high in each group at between 67.5 and 79.2 per cent, with Jobbik sympathizers being at the top and other party sympathizers at the bottom of this ranking. By 2017, the level of rejection had become even higher, the aggregated proportion of the two examined categories being between 69.7 and 91.1 per cent. The greatest change (more than 20 percentage points) happened among Fidesz sympathizers: in 2017, nine of every ten Fidesz sympathizers 
rejected the immigration of people of a different race/ethnic group. The only group in which the level of rejection of these immigrants did not change significantly was other party sympathizers.

Analysis of the question about immigrants from poorer countries outside Europe shows the highest rejection rates in both years. In 2012, the proportion of those who rejected the immigration of this group was between 71.3 and 89.9 per cent. The group that rejected it most strongly was the one of Jobbik voters, while the members of other groups rejected these immigrants at approximately the same level. Nevertheless, the rejection of these immigrants in every examined group had risen further by 2017 to between 82.6 and 96.2 per cent. The biggest change happened among Fidesz sympathizers, where the proportion of those who rejected such immigrants had grown by more than 20 percentage points. The smallest change (little more than 7 percentage points) was observed in the case of other party sympathizers.

Table 3 shows the descriptive statistics (means and standard deviations) of the variables used in the explanatory model for the presumed effect of migration. To decide if the differences between the means of the four groups were significant we used Games-Howell post-hoc tests with a significance level of 0.05 as variances across groups were not equal (Field, 2009: 374-375).

Table 3. Descriptive statistics for variables used in the path analysis

\begin{tabular}{|l|c|c|c|c|c|c|c|c|}
\hline & \multicolumn{2}{|c|}{$\begin{array}{c}\text { Presumed Effect } \\
\text { of Migration (+: } \\
\text { negative) }\end{array}$} & \multicolumn{2}{|c|}{$\begin{array}{c}\text { Legitimacy } \\
\text { Potential (+: } \\
\text { high) }\end{array}$} & \multicolumn{2}{|c|}{$\begin{array}{c}\text { Positive Outlook } \\
\text { on Life (+: } \\
\text { positiv) }\end{array}$} & \multicolumn{2}{|c|}{$\begin{array}{c}\text { Trust in People } \\
\text { (+: trust) }\end{array}$} \\
\hline mean & SD & mean & SD & mean & SD & mean & SD \\
\hline $\begin{array}{l}\text { KD12 - Fidesz- } \\
\text { KDNP } \\
\text { sympathizer }\end{array}$ & 4.79 & 1.89 & 5.81 & 1.68 & 6.75 & 1.88 & 5.01 & 2.11 \\
\hline $\begin{array}{l}\text { 2012 - Jobbik } \\
\text { sympathizer }\end{array}$ & 6.13 & 2.20 & 3.79 & 1.76 & 6.02 & 2.20 & 4.92 & 1.86 \\
\hline $\begin{array}{l}\text { 2012 - other } \\
\text { party } \\
\text { sympathizer }\end{array}$ & 5.31 & 2.06 & 3.45 & 1.70 & 5.65 & 2.06 & 4.97 & 1.90 \\
\hline $\begin{array}{l}\text { 2012 - feels } \\
\text { close to no } \\
\text { party }\end{array}$ & 5.45 & 1.91 & 3.77 & 1.75 & 5.59 & 2.15 & 4.78 & 1.95 \\
\hline $\begin{array}{l}\text { 2017 - Fidesz- } \\
\text { KDNP } \\
\text { sympathizer }\end{array}$ & 7.14 & 2.01 & 6.27 & 1.30 & 7.17 & 1.57 & 4.59 & 1.70 \\
\hline $\begin{array}{l}2017 \text { - Jobbik } \\
\text { sympathizer }\end{array}$ & 7.24 & 2.05 & 3.94 & 1.89 & 6.61 & 1.69 & 4.11 & 1.87 \\
\hline $\begin{array}{l}\text { 2017 - other } \\
\text { party } \\
\text { sympathizer }\end{array}$ & 5.39 & 2.00 & 3.74 & 1.61 & 5.95 & 1.84 & 4.75 & 1.68 \\
\hline $\begin{array}{l}\text { 2017 - feels } \\
\text { close to no } \\
\text { party }\end{array}$ & 6.53 & 2.02 & 4.19 & 1.79 & 6.48 & 2.05 & 4.68 & 1.89 \\
\hline
\end{tabular}

Source: ESS6 and ESS8 Hungarian dataset. Authors' own calculations.

All variables are measured on a $0-10$ scale. 
In 2012, the mean value for the presumed effect of immigration was not significantly different among Jobbik sympathizers, other party sympathizers, and those who did not have a party they felt close to (mean values between 5.45 and 6.13 on a scale of $0-10$ ). However, Fidesz sympathizers had a significantly lower mean value than Jobbik sympathizers and those who did not have a preferred party, which means that compared to the latter groups Fidesz supporters assumed a more positive effect from migration. There was no significant difference at that time in terms of the presumed effect of migration between Fidesz supporters and supporters of other parties (excluding Fidesz and Jobbik). In 2017, Fidesz and Jobbik sympathizers, compared to other groups, had a significantly worse opinion about the presumed effect of migration. This suggests that although in 2012 Fidesz supporters presumed a more positive effect of migration than the supporters of Jobbik, in 2017 the sympathizers of the incumbent party were on the same platform as the supporters of the far-right party regarding this issue. Although it appears that the means of all political preference groups grew from 2012 to 2017 (i.e., the opinions of all groups about the presumed effect of migration became more negative), growth was only significant in the case of Fidesz supporters and those who did not have a party to feel close to. The opinion of the other two groups (Jobbik and other party sympathizers) did not change between the two years in this regard.

In each examined year, Fidesz supporters - understandably - felt significantly higher legitimacy potential than any other political groups. The other three groups had all lower means on the legitimacy potential index and did not differ from each other significantly with regard to this question in either year. There are two groups of people who felt more legitimacy potential in 2017 than in 2012: one is the group of Fidesz sympathizers, and the other is the group of those who did not have a party preference. The perceived legitimacy potential of Jobbik and other party supporters did not change over time.

Fidesz sympathizers had a significantly more positive outlook on life than other parties and 'no party' supporters each year, except for Jobbik supporters. It is also true for both years, that the level of positive outlook was the same for all other political groups. Only Fidesz supporters and those who did not feel close to any parties had significantly higher means (thus a more positive outlook on life) in 2017 compared to 2012. The level of positive outlook did not change among Jobbik and other party supporters from 2012 to 2017.

There was no significant difference between the examined political groups according to their general trust in people in either year. There was also no significant difference between the two examined years in any political group.

As mentioned above, we used path model analysis for explaining the presumed effect of migration. In addition to the final dependent variable, the explanatory model included three variables: positive outlook on life, general trust in people, and legitimacy potential. According to our earlier analysis, we split our model into eight groups, taking into account both the year of data collection and the political preference of respondents. Figure 2 shows the results of the four models for each year. 


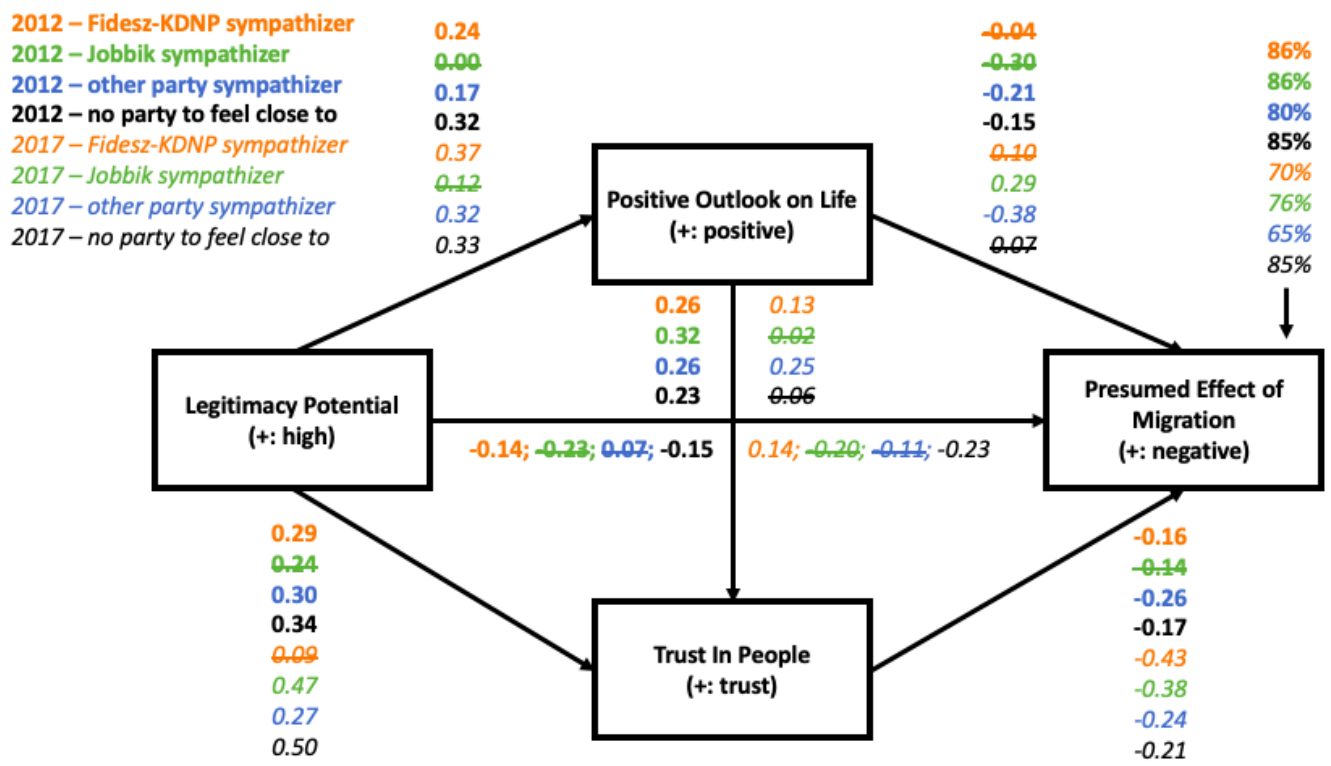

Figure 2: Path-model analysis of the presumed effect of migration (standardized regression coefficients).

Source: ESS6 and ESS8 Hungarian dataset. Authors' own calculations.

Coefficients are significant at a level of 0.05 unless indicated in strikethrough.

Controlled for age, gender, education, type of settlement, and subjective income.

In 2012, there were no meaningful differences in the explained variance of the model in terms of the examined political groups. They were quite similar to each other (1415 per cent); the only exception was the group of other party sympathizers, where explained variance was slightly higher (20 per cent); thus, the explanatory power of the model is the strongest for this group. As one can notice, there is only one significant path (effect) in the case of Jobbik sympathizers while all other effects are not significant, thus the explanatory power for that group is similar to that of the others. Most of these not significant effects are due to the relatively small sample size of this group. For all other groups it is true in 2012 that the greater legitimacy potential they felt, the more positive their outlook on life was, which resulted in stronger interpersonal trust leading to more positive assumptions about the effect of migration. In these groups, high legitimacy potential resulted in stronger interpersonal trust independently of positive outlook on life, together with a more positive attitude toward immigration. Only in the case of Fidesz supporters and those having no party preferences did high legitimacy potential in itself, independent of any micro-level variables, lead to a more positive presumed effect of migration. However, it is important to note that Fidesz supporters' positive outlook on life did not have a direct effect on the presumed effect of migration, only an indirect one through interpersonal 
trust. ${ }^{14}$ For other party sympathizers and those who did not have a party to feel close to, a positive outlook was associated with the positive presumed effect of migration.

In 2017, the explanatory power of the models was generally greater (24-35 per cent), with the group of those with no party preference being the exception where the explained variance remained the same. In the case of all groups but Jobbik, the more legitimacy was perceived, the more positive the outlook on life. However, from here the paths are different. In the case of Fidesz and other party supporters, this better outlook on life leads to stronger interpersonal trust and through this to a more positive opinion about the presumed effect of migration. In the case of other party supporters, a positive outlook on life can increase positive attitudes to migration in itself; however, in the case of Fidesz supporters, personal happiness and satisfaction needed to be accompanied by interpersonal trust for this to occur.

Nevertheless, the most important differences between the different political groups - more precisely, between Fidesz supporters and other groups - lie somewhere else. In the case of non-Fidesz supporters, we see similar effects as in 2012; namely, that legitimacy potential can affect attitudes toward migration through either micro-level satisfaction and happiness or generalized trust, or through both; higher legitimacy potential in itself increases interpersonal trust, leading to a more positive attitude towards the effects of migration. However, in the case of Fidesz supporters, this is only true if it is accompanied by micro-level happiness and satisfaction.

It is even more interesting how legitimacy potential affects the presumed effect of migration. In the case of Fidesz supporters and the group with no party preferences, legitimacy potential in itself has a direct effect, although in a very different way. In the case of those with no party preferences, the effect of 2017 is in accordance with the result of 2012 and the literature; namely, that higher legitimacy potential results in a more positive opinion of the presumed effect of migration. In the case of Fidesz supporters, it is the other way round. While in 2012 the more legitimacy potential the former felt the more positive were their opinions about the presumed effect of migration, in 2017 the direction of this effect had reversed: the more legitimacy potential they felt, the more negative was their opinion about the presumed effect of migration. However, with Fidesz supporters too, if this high legitimacy potential was accompanied with positive outlook on life leading to greater interpersonal trust, it resulted in a more positive opinion about the presumed effects of migration.

There is another major difference between the models of 2012 and 2017 that appears in the case of Jobbik supporters: namely, in terms of the effect of a positive outlook on life on the presumed effect of migration. The value of this coefficient is very similar in 2012 and 2017, but this is very likely because of the small sample size of this group that the effect was not significant in $2012(\mathrm{p}=0.08)$. Nevertheless, despite the possible impact of sample size we found it important to note this finding as the effect was negative in 2012 and positive in 2017. This means that in 2012 a positive outlook was potentially associated with a positive presumed effect of

\footnotetext{
${ }^{14}$ The same holds for Jobbik supporters, but in their case the finding was possibly caused by the low number of respondents since the value of the standardized regression coefficient is fairly high $(0.30)$.
} 
migration, while in 2017 a positive outlook attended negative opinions about the presumed effect of migration among Jobbik supporters.

\section{Discussion}

Data from the European Social Survey, like other sets of data, showed the high level of xenophobia in Hungary even before the migration crisis broke out. Little more than half of all respondents (52 per cent) even rejected the allowance of ethnic Hungarian immigrants, meaning that they would reject allowing all or some of them to immigrate to Hungary. The rejection rate was much higher for non-Hungarian immigrants (75 per cent) and those from poorer non-European countries (81 per cent). By 2017 there had been a major increase in the rejection of all kinds of immigrant groups. Since Fidesz has always been concerned with ethnic Hungarians (partly for vote-maximization purposes), it was striking to see that the proportion of Fidesz sympathizers who would allow no ethnic Hungarian immigrants had increased by more than 10 percentage points (the highest level of growth among all political preference groups). However, looking at the data for the other immigrant groups, the increase is even more remarkable. Both in the case of non-Hungarian immigrants and those from poorer non-European countries the increase was more than 20 percentage points for Fidesz, and less for the other political preference groups. Not only did the rejection of different kinds of immigrant groups increase from 2012 to 2017, but also negative opinions about their presumed effect (regarding education, culture, and overall impact). In this case, as earlier trends also show, the opinion of Fidesz sympathizers became more negative (by 2.4 points on an eleven-point scale, as opposed to the maximum of a 1.1-point change in other political preference groups). Based on the analysis of descriptive statistics, we accept our first main hypothesis: respondents' opinions about immigrants enormously deteriorated from 2012 to 2017. Moreover, the different reactions of Fidesz and non-Fidesz supporters could also be identified. The fact that the opinion of Fidesz sympathizers worsened much more in every respect leads us to assume that the anti-immigration campaign played an important role in this - either a party's sympathizers are more sensitive to its messages than non-supporters, or those who resonated more with the message of the antiimmigration campaign became Fidesz supporters and those who did not stopped supporting the party.

In the next step of our analysis we built a model to explain the formation of respondents' opinions about the presumed effect of immigrants. In this model we connected macro- and micro-level trust and satisfaction to see the mechanism by which this hatred came into existence. We decided to connect macro- and micro-level trust and satisfaction with anti-immigrant attitudes as we agree with Csepeli and Örkény (2017) who have argued that:

'(...) the refugee crisis, in addition to the political crisis, has a direct impact on everyday behavior, everyday culture and people's interpersonal relationships. What we can observe today, and perhaps the most worrisome consequence of the current situation, is that in many countries of the EU, the political and the 
moral crises that undermine values reach down to the deepest layers of society and into people's relationships. ${ }^{15}$ (Csepeli and Örkény, 2017: 74)

In 2012, the explanatory model worked in almost the same way for Fidesz and nonFidesz sympathizers, and was consistent with our assumptions. Trust and satisfaction on the macro level (that is, high legitimacy potential) resulted in positive feelings on the micro level (that is, a positive outlook on life and a high level of interpersonal trust), which led to the positive presumed effect of migration. Moreover, in the case of Fidesz supporters and the group with no party preferences high legitimacy potential appeared to produce the same result, even independently of micro-level variables. Using either route specified in the model, the result was the same.

In 2017, however, we found a strikingly different pattern in the case of Fidesz supporters: trust in and satisfaction with the system (namely, high legitimacy potential) in itself led to a more negative attitude towards migration. However, we found that high legitimacy potential could also lead to a more positive opinion about the presumed effect of migration, but only if accompanied by both a micro-level positive outlook on life and interpersonal trust. The other important change in the case of Fidesz supporters is that the indirect effect of legitimacy potential through trust on the presumed effect of migration - which existed in 2012 - had disappeared.

The fact that there were major differences between Fidesz and non-Fidesz sympathizers in every respect concerning anti-migrant attitudes led us to accept our second main hypothesis. Since we cannot separate the effect of the anti-migration propaganda and that of other contextual factors we cannot say that the difference in attitudes toward the different types of immigrant in 2012 and 2017, as well as the differences we found between Fidesz and non-Fidesz sympathizers, is due to the government's anti-immigration campaign. However, knowing the all-pervasive nature of the campaign and the fact that our results are consistent in every aspect, leads us to think that it is reasonable to assume that it had at least some effect.

In this paper we have dealt with moral panic at great length by discussing its five crucial elements and their Hungarian relevance. We would now like to refer to them in the context of our results. ESS data do not provide information about the concern people felt about the behavior of immigrants. However, the hostility felt towards the latter and the presence of substantial and widespread concern have been identified; both phenomena valid much more for Fidesz sympathizers. Knowing that the proportion of foreign citizens in Hungary is less than two per cent of the whole Hungarian population, and that after September 2015 the number of asylum-seekers dramatically decreased, these heightened and extremely negative emotions seem to be disproportionate. As we have stated above, it is perhaps too early to comment on the volatility of this moral panic, although it is a fact that its outbreak was rapid. We have found it important to prove that Hungarian society has been in a state of moral panic, arguing that the landslide effects the anti-immigration campaign had, as supported by our analysis, could hardly have been achievable without this.

\footnotetext{
${ }^{15}$ Original text in Hungarian: '[a] menekültkrízis tehát a politikai válságon felül közvetlenül is kihat a köznapi viselkedésre, a mindennapi kultúrára és az emberek egymás közötti kapcsolataira. Amit megfigyelhetünk napjainkban, és ami talán a legaggasztóbb következménye a jelenleg kialakult helyzetnek, hogy az EU számos országában a társadalmi mélyrétegekbe és az emberek egymás közti kapcsolataiba is lecsorog a politikai és az értékeket alásó morális krízis.'
} 
We also found that the difference in attitudes between supporters and nonsupporters of the governing party increased from 2012 to 2017. Not only had Fidesz sympathizers became more negative about migration and migrants by 2017 , but the paths leading from macro-level trust and satisfaction to opinions about migration also differed more (direct and indirect effects were different for those who supported Fidesz compared to other groups). Additionally, the causatory mechanisms of the development of opinions in the case of Fidesz supporters differed from those of other party preference groups.

\section{References}

Angelusz, R. and Tardos, R. (2005) A választói tömbök rejtett hálózata (The hidden network of electoral clusters). In: Angelusz, R and Tardos, R. (eds.) Törések, hálók, hidak. Választói magatartás és politikai tagolódás Magyarországon (Cleavages, nets, bridges: Voter behavior and political clustering in Hungary). Budapest: Demokrácia Kutatások Magyar Központja Alapítvány. 65-160.

Barlai, M. and Sik, E. (2017) A Hungarian trademark (a "Hugarikum"): the moral panic button. In: Barlai, M., Fähnrich, B., Griessler, Ch. and Rhomberg, M. (eds.) The migrant crisis: European perspectives and national discourses. Münster: LIT Verlag. 147-169.

Barna, I. (2019) Anti-Immigrant Propaganda and the Factors That Led to its Success in Hungary." In Narratives of Memory, Migration, and Xenophobia in the European Union and Canada, edited by Helga Hallgrimsdottir and Helga Thorson. Victoria: University of Victoria, forthcoming.

Barna, I. and Hunyadi, B. (2016) Report on xenophobia, discrimination, religious hatred and aggressive nationalism in Hungary in 2015.

http://politicalcapital.hu/pc-

admin/source/documents/Report\%20on\%20xenophobia_Hungary_2015_Final. pdf Accessed: 26-09-2018.

Barna, I. and Koltai, J. (2018) A bevándorlókkal kapcsolatos attitűdök belső szerkezete és az attitűdök változása 2002 és 2015 között Magyarországon a European Social Survey (ESS) adatai alapján (The inner structure and change of attitudes toward migrants between 2002 and 2015 in Hungary based on data from the European Social Survey (ESS)). Socio.hu, 8(2): 4-23. https://doi.org/10.18030/socio.hu.2018.2.4

Bernáth, G. and Messing, V. (2015) Bedarálva. A menekültekkel kapcsolatos kormányzati kampány és a tőle független megszólalás terepei. (Wiped out: The government's anti-immigration campaign and opportunities to raise an independent voice). Médiakutató, 16(4): 7-17.

Bernáth, G. and Messing, V. (2016) Infiltration of political meaning-production: security threat or humanitarian crisis. The coverage of the refugee 'crisis' in the Austrian and Hungarian media in early autumn 2015. Budapest: CEU CMDC Working Papers Series. 
https://cmds.ceu.edu/sites/cmcs.ceu.hu/files/attachment/article/1041/infiltration ofpoliticalmeaningfinalizedweb.pdf Accessed: 15-04-2019.

Boelhouwer, J. (2016) The mood in Europe. opinions on democracy, trust, migrants and life satisfaction. In: Boelhouwer, J., Kraaykamp, G. and Stoop, I. (eds.) Trust, life satisfaction and opinions on immigration in 15 European countries. The Hague: Netherlands Institute for Social Research, SCP. 10-27.

Bértoa, F. C. (2014) Party systems and cleavage structures revisited: A sociological explanation of party system institutionalization in East Central Europe. Party Politics, 20(1): 16-36. https://doi.org/10.1177/1354068811436042

Boda, D. and Simonovits, B. (2016) Reason for flight: Does it make a difference? In: Simonovits, B. and Bernáth, A. (eds.) The social aspects of the 2015 migration crisis in Hungary. Budapest: Tárki. 48-57.

Boros, J. (2018) Migránsnak néztek egy csongrádi nőt, mert kendő volt a fején (A woman from Csongrád was believed to be a migrant for wearing a headscarf). 444.hu, March 29, https://444.hu/2018/03/29/migransnak-neztek-egy-csongradinot-mert-kendo-volt-a-fejen Accessed: 29-09-2018.

Ceobanu, A. M. and Escandell, X. (2008) East is West? National feelings and antiimmigrant sentiment in Europe. Social Science Research, 37(4): 1147-1170. https://doi.org/10.1016/j.ssresearch.2008.01.002

Csepeli, Gy. and Örkény, A. (2017) Nemzet és migráció (Nation and migration). Budapest: ELTE Társadalomtudományi Kar.

Cohen, S. (2002) Folk devils and moral panics. The creation of the mods and rockers. London and New York: Routledge.

Ekici, T. and Yucel, D. (2015) What determines religious and racial prejudice in Europe? The effects of religiosity and trust. Social Indicators Research, 122(1): 105-133. https://doi.org/10.1007/s11205-014-0674-y

Enyedi, Zs. (2004) A voluntarizmus tere: a pártok szerepe a törésvonalak kialakulásában (The sphere of voluntarism: the role of parties in cleavage formation). Századvég, 9(33): 5-26.

Field, A. (2009) Discovering statistics using SPSS (and sex and drugs and rock ' $n$ ' roll). London: Sage Publications.

Gerő, M., Płucienniczak, P. P., Kluknavksa, A., Navrátil, J. and Kanellopoulos, K. (2017) Understanding enemy images in Central and Eastern European politics: Towards an interdisciplinary approach. Intersections, 3(3): 14-40. https://doi.org/10.17356/ieejsp.v3i3.365

Goździak, E. M. and Márton, P. (2018) Where the wild things are: Fear of Islam and the anti-refugee rhetoric in Hungary and in Poland. Central and Eastern European Migration Review, 7(2): 125-151.

https://doi.org/10.17467/ceemr.2018.04 
Goode, E. and Ben-Yehuda, N. (2009) Moral panics: The social construction of deviance. Chichester: Wiley-Blackwell.

Herreros, F. and Criado, H. (2009). Social trust, social capital and perceptions of immigration. Political Studies, 57(2): 337-355. https://doi.org/10.1111/j.14679248.2008.00738.x

Kovarek, D., Róna, D., Hunyadi, B. and Krekó P. (2017) Scapegoat-based policy making in Hungary: Qualitative evidence for how Jobbik and its mayors govern municipalities. Intersections, 3(3): 63-87.

https://doi.org/10.17356/ieejsp.v3i3.382

Körösényi, A. (2013) Political polarization and its consequences on democratic accountability. Corvinus Journal of Sociology and Social Policy, 4(2): 3-30.

Kmetty, Z. (2015) Ideológiai és kapcsolathálózati törésvonalak a társadalmi-politikai térben a 2014-es országgyűlési választások előtt (Ideological and network connectivity breakpoints in the socio-political sphere before the 2014 parliamentary elections). In: Szabó, G. (ed.) Studies in Political Science Politikatudományi Tanulmányok. 2015. No. 1. Budapest: MTA TK PTI. 834.

McLaren, L. M. (2003) Anti-immigrant prejudice in Europe: Contact, threat perception, and preferences for the exclusion of migrants. Social Forces, 81(3): 909-936. https://doi.org/10.1353/sof.2003.0038

Meuleman R., Lubbers, M. and Kraaykamp, G. (2016) Opinions on migration in a European perspective: Trends and differences. In: Boelhouwer, J., Kraaykamp, G. and Stoop, I. (eds.) Trust, life satisfaction and opinions on immigration in 15 European countries. The Hague: Netherlands Institute for Social Research, SCP. 28-51.

Paas, T. and Halapuu, V. (2012) Attitudes towards immigrants and the integration of ethnically diverse societies. NORFACE Migration Discussion Paper No. 201223.

Available at: http://www.norface-migration.org/publ_uploads/NDP_23_12.pdf

Pivarnyik, B. (2017) The day Orbán openly condoned hate and bigotry. The Budapest Beacon, October 2, https://budapestbeacon.com/day-orban-openlystood-hate-bigotry/ Accessed: 29-09-2018.

Rényi, P. D. (2017) Félelem és reszketés Kömlőn: migránsnak hitték a mindenszentekre látogatóba érkező magyarokat (Fear and trembling in Kömlő: Hungarians coming to the village for All Saints' Day were believed to be migrants). 444.hu, November 2, https://444.hu/2017/11/02/felelem-es-rettegeskomlon-migransnak-hittek-a-mindenszentekre-latogatoba-erkezo-magyarokat Accessed: 29-09-2018.

Rustenbach, E. (2010) Sources of negative attitudes toward immigrants in Europe: A multi-level analysis. International Migration Review, 44(1): 53-77.

https://doi.org/10.1111/j.1747-7379.2009.00798.x 
Sides, J. and Citrin, J. (2007) European opinion about immigration: The role of identities, interests and information. British Journal of Political Science, 37(3): 477-504. https://doi.org/10.1017/S0007123407000257

Sik, E. (2016) The socio-demographic basis of xenophobia in contemporary Hungary. In: Simonovits, B. and Bernath, A. (eds.) The social aspects of the 2015 migration crisis in Hungary. Budapest: Tárki. 41-47.

Sik E., Simonovits, B. and Szeitl, B. (2016) Az idegenellenesség alakulása és a bevándorlással kapcsolatos félelmek Magyarországon és a visegrádi országokban (Xenophobia and fears connected to immigration in Hungary and the Visegrád countries). Regio, 24(2): 81-108. https://doi.org/10.17355/rkkpt.v24i2.114

Simonovits, B. and Szeitl, B. (2016) Menekültekkel és migrációs politikával kapcsolatos attitűdök Magyarországon és nemzetközi összehasonlításban (Attitudes toward immigrants and immigration policy in Hungary and in international comparison). In: Kolosi, T. and Tóth, Gy. I. (eds.) Társadalmi riport (Social report). Budapest: Tárki. 420-439.

Soós, G. (2012) Kétblokkrendszer magyarországon (Two-block-system in Hungary). In: Boda, Zs. and Körösényi, A. (eds.) Van irány? Trendek a magyar politikában (Is there a direction? Trends in Hungarian politics). Budapest: Új Mandátum and MTA TK PTI. 14-40.

Spike, J. (2017a) Fidesz mayors, MPs would prevent refugees from vacationing at Lake Balaton. The Budapest Beacon, August 8,

https://budapestbeacon.com/fidesz-mayors-mp-prevent-refugees-vacationinglake-balaton/ Accessed: 29-09-2018.

Spike, J. (2017b) 'Hatred of refugees has fundamentally changed the town' Hungarian village succumbs to state propaganda. The Budapest Beacon, September 28,

https://budapestbeacon.com/hatred-refugees-fundamentally-changed-townhungarian-village-succumbs-state-propaganda/ Accessed: 29-09-2018.

Stokes, B., Wike, R. and Poushter, J. (2016) Europeans face the world divided. http://www.pewglobal.org/2016/06/13/europeans-face-the-world-divided/ Accessed 10-03-2019.

Uslaner, E. M. (2007) The foundations of trust: macro and micro. Cambridge Journal of Economics, 32(2): 289-294. https://doi.org/10.1093/cje/bem039

Tóka, G. (2005) A magyarországi politikai tagoltság nemzetközi összehasonlításban (Hungarian political Clustering in International Comparison). In Angelusz, R. and Tardos, R. (eds.) Törések, hálók, hidak. Választói magatartás és politikai tagolódás Magyarországon (Cleavages, Nets, Bridges: Voter Behavior and Political Clustering in Hungary). Budapest: Demokrácia Kutatások Magyar Központja Alapítvány. 17-64.

van der Linden, M., Hooghe, M., de Vroome, T. and Van Laar, C. (2017) Extending trust to immigrants: Generalized trust, cross-group friendship and anti- 
immigrant sentiments in 21 European societies. PLOS One, 12 (5): e0177369. https://doi.org/10.1371/journal.pone.0177369

Walker, V. S. and Gyori, L. (2018) Migrants, moral panic, and intolerance in Hungarian politics. War on the Rocks, July 24,

https://warontherocks.com/2018/07/migrants-moral-panic-and-intolerance-inhungarian-politics/ Accessed: 22-(09-2018.

Wike, R. (2016) Four factors driving anti-establishment sentiment in Europe. Pew Research Center, December 6, http:/www.pewresearch.org/fact-tank/2016/12/06/4-factors-driving-antiestablishment-sentiment-in-europe/ Accessed: 22-09-2018. 